\title{
IMPLEMENTASI KEBIJAKAN SMART CITY DALAM MEWUJUDKAN KUALITAS PELAYANAN PUBLIK DI KOTA TANGERANG
}

\author{
Syamsul Bahri ${ }^{1}$, Khasan Effendy ${ }^{2}$, Ngadisah $^{3}$, Sampara Lukman $^{4}$ \\ Institut Pemerintahan Dalam Negeri (IPDN) \\ Email: syamsulb1973@gmail.com
}

\begin{abstract}
Abstrak
Permasalahan yang diangkat dalam penelitian ini adalah terkait dengan implementasi kebijakan smart city dalam mewujudkan pelayanan publik berkualitas di Kota Tangerang yang dititik beratkan kepada pemanfaatan teknologi informasi dan komunikasi melalui internet, online, digital dan media sosial. Metode penelitian yang digunakan adalah metode deskriptif dengan pendekatan kualitatif. Hasil penelitian menunjukkan bahwa implementasi kebijakan smart city dalam mewujudkan pelayanan publik berkualitas di Kota Tangerang belum bisa terlaksana secara efektif dalam meningkatkan kesejahteraan masyararakat secara faktual dari faktor-faktor yang mempengaruhi mencakup; (1) komunikasi mempengaruhi terkait dari semua indikator yang ada, dan masih kurang efektif indikator ketrampilan; (2) Sumber daya terkait dari semua indikator yang ada, dan masih kurang efektif ketrampilan tersedianya sarana dan prasarana yang dibutuhkan; (3) Disposisi terkait dari semua indikator yang ada, dan kurang efektif tingkat kepercayaan kebijakan diambil pimpinan; (4) Struktur birokrasi terkait dari semua indikator yang ada, dan yang masih kurang efektif instruktif sesuai dengan Standard Operating Procedure (SOP).
\end{abstract}

Kata Kunci: Implementasi Kebijakan, Smart City, Pemerintahan yang Cerdas.

\section{Abstract}

The problems that arise in this research are related to the implementation of policy policies in realizing quality public services in in Tangerang City which focuses on the use of information and communication technology via the internet, online, digital and social media. The research method used is descriptive method with a qualitative approach. The results showed that the implementation of the smart city policy in realizing quality public services in Tangerang City could not be implemented effectively in improving the welfare of the community in fact from the factors that influence including; (1) communication that affects all existing indicators, and skills indicators are still not effective; (2) Relevant resources from all the existing indicators, and lack of effective skills in the provision of facilities and infrastructure needed; (3) The related disposition of all the existing indicators, and the less effective level of trust taken by the leadership; (4) Bureaucratic structures related to all existing indicators, and which are still less effective and instructive according to the Standard Operating Procedure (SOP).

Keywords: Policy Implementation, Smart City, Smart Government.

\section{A. PENDAHULUAN}

Isu perkembangan smart city atau dikenal dengan kota pintar/kota cerdas di Indonesia saling berlomba-lomba untuk menerapkannya perubahan dalam kehidupan teknologi 
informasi dan komunikasi melalui internet, online dan digital. Kecanggihan teknologi informasi dan komunikasi segala aktivitas yang dilakukan oleh manusia sering bersinggungan dengan internet, online, digital, dan media sosial (Utomo \& Hariadi, 2016).

Permasalahan perkotaan mulai dari sampah, edukasi, transpotasi, sosial ekonomi, bencana, budaya, kesehatan, pendidikan, agama, olahraga, perdagangan, bisnis, dan pemerintahan semuanya menyebarkan informasi berbasis internet, online dan digital (Ahmadjayadi, 2016). Penggunaan teknologi internet, online dan digital memunculkan misalkan; smart city, e-learning, e-book, e-commerce, dan e-government (Hidayatulloh, 2016).

Penerapan smartcity tidak terjadi secara langsung dengan menerapkan e-government, e-budgeting, e-planning yang telah terintegrasi, dan terdapat program dalam pelaksanaannya seperti perencanaan kota, pengelolaan lingkungan, dan lain sebagainya (Insani, 2017). Hal tersebut masih dalam tahap proses pengaturan, pembangunan, pemberdayaan, dan pelayanan masyarakat di daerah yang berkembang secara bertahap, dikarenakan adanya kendala biaya dan sumber daya manusia dalam pemicu untuk mengeluarkan ide dan inovasi baru terutama sains serta teknologi masa mendatang untuk memaksimalkan kepada warganya dalam mendukung proses pengaturan, pembangunan, pemberdayaan, dan pelayanan yang sesuai dengan kebutuhan penggunanya (Gaur, dkk., 2015).

Di sisi lain, masyarakat yang semakin modern dan mapan, memiliki segudang ekspektasi, seperti; lingkungan tempat tinggal dan pekerjaan yang nyaman, adanya area publik yang memadai, serta kemudahan mengurus segala bentuk pelayanan publik . (Supangat, dkk., 2015). Persoalan smartcity menjadi solusi bagi pemerintah daerah dalam menyoroti berbagai permasalahan yang muncul di perkotaan yang dipimpinnya (Dameri, 2013).

Penyebab masih belum efektif implementasi kebijakan smart city dalam mewujudkan kualitas pelayanan publik di Provinsi Banten yang terjadi dilapangan terlihat dari intisari kerangka teori Edwards III (1980) yang menyatakan adanya empat faktor utama antara lain:

1. Komunikasi; kurang lancar sehingga musyawarah menemui jalan buntu. Hal ini karena ketidakjelasan dalam penyampaian informasi kepada masyarakat mengenai seperti apa kebijakan smart city yang ditetapkan pemerintah smart city dalam mewujudkan kualitas pelayanan publik di Provinsi Banten, dan tidak adanya konsistensi teknologi informasi dan komunikasi mengenai berapa besar biaya yang dibayar masyarakat. Masalah ketidakjelasan teknologi informasi dan komunikasi 
hadir karena terdapatnya variansi kurang akurat yang disampaikan oleh pemerintah kepada masyarakat.

2. Sumberdaya; minimnya ketersediaan sarana dan prasarana yang dibutuhkan untuk pembangunan teknologi informasi dan komunikasi yang mengharuskan dilakukannya pemerintaha daerah sehingga bernilai tinggi, dan minimnya anggaran dana yang dibutuhkan tidak sesuai dengan nilai riil teknologi informasi dan komunikasi digunakan.

3. Struktur birokrasi; cenderung bersifat massal, sehingga peran struktur birokrasi sangat dominan baik dalam penentuan harga, cara tawar dan waktu pembayaran.

4. Disposisi; para pelaksana yang menetapkan secara sepihak waktu pembayaran yang cenderung merugikan masyarakat. Keadaan ini merefleksikan kurangnya perhatian dari pemerintah permasalahan smart city dalam mewujudkan kualitas pelayanan publik di Provinsi Banten (Edward III, 1980).

Pembaharuan dalam penyelenggaraan Pemerintahan Daerah berbagai sektor sebagai suatu langkah untuk mengatasi tuntutan masyarakat yang semakin kompleks (Gaebler, 1993). Inovasi menjadi suatu mesti dilakukan keberadaan pemerintah menjadi bermakna di mata rakyatnya. Dalam pelaksanaan kebijakan Pemerintahan Daerah mengacu pada prinsip: peningkatan efisiensi; perbaikan efektivitas; perbaikan pengaturan; pembangunan; pemberdayaan; pelayanan; tidak ada konflik kepentingan; berorientasi kepada kepentingan umum; dilakukan secara terbuka; memenuhi nilai kepatutan; dan dipertanggungjawabkan hasilnya, serta tidak untuk kepentingan diri sendiri (Wasistiono, 2002).

Kebijakan smart city Kota Tangerang dalam mewujudkan kualitas pelayanan publik di Kota Tangerang pemerintahan yang cerdas memiliki jumlah penduduk yang lebih banyak. Hal ini dipicu dengan pemusatan fasilitas hidup yang lebih baik di daerah perkotaan. Jumlah penduduk yang besar, tidak merata, dan tidak dikelola dengan baik menimbulkan beragam masalah. Pemasalahan yang muncul bukan saja terkait dengan masalah sosial, tetapi juga lingkungan hidup dan kualitas hidup masyarakat.

Pembangunan teknologi informasi dan komunikasi dalam pengembangan eGovernment pada hakikatnya merupakan proses transformasi pelayanan publik dari pelayanan manual ke pelayanan elektronik, maka untuk mencapai tujuan tersebut, dibutuhkan upaya sistematis yang menyangkut subyek, obyek dan metoda yang terkait dengan proses transformasi (Holle, 2011). Proses transformasi ini mengacu pada tiga hal, yaitu perundangundangan di bidang teknologi informasi dan komunikasi, berdampak lingkungan yang 
bersumber pada tuntutan pelayanan publik serta kemajuan teknologi informasi dan komunikasi terjangkau oleh seluruh lapisan masyarakat pengguna dalam sebuah Kota Tangerang (Ramadhan, dkk., 2019).

Implementasi kebijakan smart city dalam mewujudkan kualitas pelayanan publik di Kota Tangerang kini menjadi impian banyak kota besar di Indonesia (Kurnaedi, 2017). Dalam mewujudkan smart government sebagai solusi permasalahan perkotaan khususnya di Kota Tangerang mengatasi isu strategis dalam mendukung proses pengaturan, pembangunan, pemberdayaan, dan pelayanan bagi penduduk untuk mempercepat kinerja pemerintahan (Ratama \& Munawaroh, 2019).

Berdasarkan uraian latar belakang di atas, maka tujuan penelitian ini adalah menganalisis implementasi kebijakan Smart city dalam mewujudkan kualitas pelayanan publik di Kota Tangerang.

\section{B. METODE}

Desain penelitian yang digunakan dalam penelitian ini adalah desain analisis deskriptif dengan pendekatan kualitatif. Locke, Spriduso dan Silferman (dalam Creswell, 1994) mengemukakan bahwa "qualitative research is interpretative research. As such, the biases, values and judgement of the researches become stated explicitly in the research report. Such openess is considering to be useful and positive”. Hal yang sama, Moleong (2008) menyatakan bahwa "metode penelitian kualitatif sebagai prosedur penelitian yang menghasilkan data deskriptif berupa kata tertulis atau lisan dari orang-orang dan perilaku yang diamati. Penelitian kualitatif lebih menghendaki arah bimbingan penyusunan teori substantif yang berdasarkan data".

Keseluruhan data hasil penelitian dilakukan analisis secara deskripsi secara mendalam untuk memahami arti (meaning) dan mengerti secara faktual (verstehen) terhadap kondisi empirik yang sesungguhnya dengan beragam variasi empirik dari obyek penelitian. Hasil penelitian yang diperoleh melalui potret empirik didekatkan dengan teori yang relevan untuk dilakukan interpretasi dalam usaha mengetahui derajat perkembangan faktual dari obyek penelitian diketahui batasan cangkauan kemampuan teori dalam menjelaskan perkembangan fakta empirik yang ada dan keterbatasan fakta yang ada dalam memenuhi patokan teori yang ada (Bungin, 2008). 


\section{HASIL DAN PEMBAHASAN}

Implementasi kebijakan smart city Kota Tangerang dalam mewujudkan smart governance merupakan bagian penting untuk membiayai pengaturan, pembangunan, pemberdayaan, dan memudahkan pelayanan kepada masyarakat yang terus dilaksanakan. Dimaklumi bahwa Negara dalam menyelenggarakan pemerintahan mempunyai kewajiban untuk menjaga kepentingan rakyatnya, bahwa dalam bidang keamanan, pertahanan, dan kesejahteraan maupun kecerdasan kehidupannya.

Implementasi kebijakan smart city Kota Tangerang dalam mewujudkan smart governance dengan pengaturan, pembangunan, pemberdayaan, dan memudahkan pelayanan kepada masyarakat adalah iuran kepada Negara yang dipaksakan yang terutang peraturan dengan tidak mendapat prestasi (balas jasa) kembali yang langsung ditunjuk, dan gunanya adalah untuk membiayai pengeluaran keperluan umum berhubung dengan tugas negara untuk menyelenggarakan pemerintahan.

karakteristik implementasi kebijakan smart city Kota Tangerang dalam mewujudkan smart governance dengan pengaturan, pembangunan, pemberdayaan, dan memudahkan pelayanan kepada masyarakat yang bertanggungjawab menyusun rencana strategis sebagai dasar dalam melaksanakan kegiatan sesuai dengan tugas pokok dan fungsinya. Rencana strategis ini disusun dengan mencermati dan melakukan analisis terhadap kondisi lingkungan yang terus berubah yang ada dan muncul di depan kemudian. Sebelum memulai implementasi kebijakan smart city Kota Tangerang dalam mewujudkan smart governance dengan pengaturan, pembangunan, pemberdayaan, dan memudahkan pelayanan kepada masyarakat yang sebenarnya, peran dan tangggungjawab semua pihak terkait, alokasi anggaran belanja untuk pelaksanaan dan sistem koordinasi belum memadai. Mengingat implementasi kebijakan smart city Kota Tangerang dalam mewujudkan smart governance dengan pengaturan, pembangunan, pemberdayaan, dan memudahkan pelayanan kepada masyarakat berkaitan dengan memberikan implikasi terhadap realisasi pendapatan secara ketat dari semua pihak yang terkait.

Masalah faktor-faktor implementasi kebijakan smart city Kota Tangerang dalam mewujudkan smart governance dengan pengaturan, pembangunan, pemberdayaan, dan memudahkan pelayanan kepada masyarakat menyangkut unsur pelaksanaan kebijakan dan masyarakat sebagai obyek pengguna dari kebijakan yang dilaksanakan atau dilakukan sesuai dengan tujuan yang digunakan bahwa terdapat empat syarat penting guna mengkaji dan 
meneliti berhasil tidaknya implementasi kebijakan, yaitu faktor komunikasi, sumber daya, disposisi atau sikap pelaksana dan struktur birokrasi (Edward III, 1980).

\section{Komunikasi}

Faktor komunikasi memegang peranan penting dalam kehidupan manusia, karena aktivitas primer manusia yang merupakan perekat diantara individu, kelompok, komunitas, dan organisasi yang ada dalam masyarakat (Pawito, 2007). Melalui faktor komunikasi, manusia bisa saling memahami, mengembangkan diri, mengekspresikan gagasan dan emosi, menyelesaikan masalah, saling mengingatkan kepada kebaikan, menyebarkan pengetahuan, dan pengembangan budaya (Cafezio \& Morehouse, 1998). Melalui faktor komunikasi, manusia mengambil keputusan, menghibur diri, melestarikan nilai tradisional, menyebarkan inovasi terkait dengan implementasi kebijakan smart city di Kota Tangerang dalam mewujudkan smart governance meliputi; pengaturan, pembangunan, pemberdayaan, dan memudahkan pelayanan kepada masyarakat dilakukan oleh Pemerintah Kota Tangerang kepada masyarakat dalam upaya memberikan informasi bahwa untuk memudahkan dan meringankan beban masyarakat dalam memperoleh smart city Kota Tangerang dalam mewujudkan smart governance kepada masyarakat.

Implementasi kebijakan faktor komunikasi ini ditangkap oleh pemerintah yang menerima masukan dari masyarakat bahwa keengganan masyarakat dalam implementasi kebijakan terkait erat dengan mahalnya biaya untuk memperoleh smart city Kota Tangerang dalam mewujudkan smart governance kepada masyarakat terkait latar belakang kebudayaan, dimana makna suatu pesan terwujud dari pola pikir seseorang melalui sesuatu yang sering dilakukan antara pengirim dan penerima pesan maka aktivitas komunikasi semakin efektif.

Adapun yang menjadi prioritas pemerintah Kota Tangerang dituntut memiliki akuntanbilitas baik kepada masyarakat maupun pemerintah, kerena keduanya merupakan penyelenggara memperoleh smart city Kota Tangerang dalam mewujudkan smart governance kepada masyarakat. Adanya otonomi dalam pengelolaan memperoleh smart city Kota Tangerang dalam mewujudkan smart governance kepada masyarakat merupakan potensi bagi Aparatur Sipil Negara (ASN) untuk meningkatkan kinerja para personel. Kemampuan personel dalam berkomunikasi melalui umpan balik (feedback) diberikan dan menawarkan partisipasi secara langsung pihak terkait untuk meningkatkan pemahaman masyarakat terhadap penyelenggaraan memperoleh smart city Kota Tangerang dalam mewujudkan smart governance kepada masyarakat. 
Faktor komunikasi menghendaki yang mana kebijakan smart city Kota Tangerang dalam mewujudkan smart governance disampaikan tidak saja kepada pelaksana (implementors), tetapi juga kepada kelompok sasaran kebijakan dan pihak yang berkepentingan, baik langsung maupun tidak langsung terhadap kebijakan tersebut. Karenanya faktor komunikasi mencakup transformasi kebijakan, kejelasan dan konsistensi. Transformasi kebijakan ditransformasikan kepada para pelaksana, kelompok sasaran, dan pihak lain yang terkait dengan implementasi kebijakan smart city Kota Tangerang dalam mewujudkan smart governance.

Diketahui bahwa implementasi kebijakan smart city Kota Tangerang dalam mewujudkan smart governance belum efektif. Padahal komunikasi internal telah diatur yang mengarahkan dan mengedepankan pendelegasian peran dan wewenang ke tingkat pelaksana yang paling dekat dengan masyarakat, akan tetapi hasilnya dirasakan belum memadai. Hal ini disebabkan adanya masyarakat menganggap sulit dikendalikan. Efektifitas dilakukan dalam upaya memberikan informasi bahwa kebijakan smart city Kota Tangerang dalam mewujudkan smart governance untuk memudahkan memperoleh komunikasi dari pemerintah, bahkan keengganan masyarakat dalam yang ditranformasikan kepada para pelaksana, target group, dan pihak lain yang berkepentingan langsung maupun tidak langsung terhadap kebijakan smart city Kota Tangerang dalam mewujudkan smart governance diterima dengan jelas, sehingga di antara pemerintah dan masyarakat mengetahui apa yang menjadi maksud, tujuan, dan sasaran serta substansi dari kebijakan smart city Kota Tangerang dalam mewujudkan smart governance.

\section{Sumberdaya}

Keberadaan resources (sumberdaya) memiliki arti dan peranan yang besar dalam kehidupan implementasi kebijakan smart city Kota Tangerang dalam mewujudkan smart governance. Salah satu strategi pembangunan dan manajemen kota yang masih baru muncul dan berkembang seiring dengan perkembangan zaman dan teknologi. Tercapainya tujuan implementasi kebijakan smart city Kota Tangerang dalam mewujudkan smart governance dengan cepat dan mudah adalah sumbangan yang besar dari sumber daya dirancang guna membantu berbagai kegiatan masyarakat serta memberikan kemudahan mengakses informasi kepada masyarakat,

Sehubungan dengan diperlukannya sumber daya yang mencakup; modal yang berupa uang; dan material atau bahan baku, informasi, mesin-mesin, peralatan, perlengkapan, gedung kantor, waktu dan personel. Memperhatikan sumber daya modal berupa uang, tentu 
sangat masuk akal karena tanpa uang maka implementasi kebijakan smart city Kota Tangerang dalam mewujudkan smart governance sulit untuk hidup apalagi berkembang, karena sebagian besar kehidupan kebijakan smart city Kota Tangerang dalam mewujudkan smart governance memerlukan pembiayaan dalam bentuk modal yang cukup untuk memenuhi kebutuhan operasional yang relatif besar.

Pembentukan implementasi kebijakan smart city Kota Tangerang dalam mewujudkan smart governance dengan memperhatikan memiliki keterampilan yang sesuai kapasitas, peran, dan dukungan anggaran. Regulasi Kota Tangerang smart city disusun terutama terkait berbagi teknologi informasi dan teknlogi pendanaan, dokumentasi, maupun pedoman kerjasama/investasi bagi pihak ketiga. Kota Tangerang memperhatikan norma/etika/budaya setempat yang berdasar profesionalisme. Sumber daya manusia dalam kehidupan memiliki keterampilan yang sesuai komitmen, peran serta, dan pengabdian Perguruan Tinggi Negeri/Perguruan Tinggi Swasta di Kota Tangerang dalam pendayagunaan teknologi informasi komunikasi untuk implementasi kebijakan smart city Kota Tangerang dalam mewujudkan smart governance sehingga diharapkan memperbaiki tata kelola Pemerintah Kota Tangerang yang lebih baik dan lebih cerdas dalam memberikan pengaturan, pembangunan, perberdayaan, dan pelayanan kepada masyarakat. Oleh karena itu sumber daya manusia aparatur sipil negara sangat berperan dalam menjabarkan makna dari fungsi pemerintahan melaksanakan dengan efektif dan efisien.

Peningkatan sumber daya manusia dalam proses kehandalan informasi dalam penyediaan sarana dan prasarana yang menunjang proses kehandalan informasi kebijakan smart city Kota Tangerang dalam mewujudkan smart governance. Penyediaan infrastruktur yang menunjang investasi dan tenaga kerja yang berkualitas sehingga bekerja dengan dukungan kehandalan informasi memang sangat diperlukan. Dukungan sumber daya manusia tersebut jangan dinilai dari kuantitasnya. Kualitas dinilai secara cermat, dengan dukungan sumber daya manusia tersebut diandalkan untuk mengefektifkan proses implementasi kebijakan smart city Kota Tangerang dalam mewujudkan smart governance.

Tanggungjawab disertai wewenang yang mewadai adalah faktor yang sangat penting dalam pemerintahan. Di lihat dari sudut momentum, wacana dan tindakan tentang tanggungjawab untuk Indonesia saat ini merupakan conditio sie qua non. Begitu penting sehingga salah satu tanggungjawab pemerintah dianggap tidak berbuat atau melalaikan tanggungjawab disertai wewenang yang mewadai kepada rakyat. Taliziduhu (2003), mengatakan bahwa dalam sisi yang lain, sejauh manakah seorang pelaku pemerintahan 
bertanggungjawabnya. Tanggungjawab disertai wewenang yang mewadai penyelenggaraan pemerintahan Kota Tangerang yang dimaksudkan implementasi kebijakan smart city Kota Tangerang dalam mewujudkan smart governance adalah pelaksanaan tugas, penetapan janji, dan tindakan sesuai dengan keputusan batin yang diambil berdasarkan kebebasan memilih. Oleh karena itu tanggungjawab disertai wewenang yang mewadai dilakukan sejak seorang pelaku pemerintahan menerima suatu jabatan dan dilantik atau disumpah sejak pemerintah menyatakan bahwa mengerjakan sesuatu hal atas inisiatif sendiri.

Tersedianya sarana dan prasarana yang dibutuhkan untuk implementasi kebijakan smart city Kota Tangerang dalam mewujudkan smart governance, dibutuhkan perencanaan dan komitmen yang sungguh-sungguh serta keterlibatan seluruh pemangku kepentingan yang ada di Kota Tangerang. Tidak jarang smart city diartikan dengan penggunaan teknologi dalam pengelolaan kota, dan mengabaikan partisipasi masyarakat dalam proses pengaturan, pembangunan, pemberdayaan, dan pelayanan masyarakat Kota Tangerang. Penggunaan teknologi informatika komunikasi (TIK) merupakan alat dalam proses smart city. Dalam pembangunan smart city yang terintegrasi oleh Kota Tangerang meliputi; teknologi, manusia, dan institusi. Dalam upaya mengintegrasikan ketiga tersebut smart city diperlukan yang tidak berfokus pada perubahan yang direncanakan tetapi ada perubahan yang tidak direncanakan.

Dalam rangka implementasi kebijakan smart city Kota Tangerang dalam mewujudkan smart governance dibutuhkan perencanaan dan komitmen yang sungguh-sungguh dan keterlibatan seluruh pemangku kepentingan yang ada di Kota Tangerang. Penggunaan teknologi dalam pengelolaan kemampuan menggunakan sarana dan prasarana teknologi Kota Tangerang mengabaikan partisipasi masyarakat dalam proses pengaturan, pembangunan, pemberdayaan, dan pelayanan Kota Tangerang. Penggunaan teknologi informatika dan komunikasi merupakan alat dalam proses dalam pembangunan smart city yang terintegrasi oleh kota yaitu teknologi, manusia, dan institusi.

\section{Disposisi}

Disposisi kecenderungan sikap aparatur yang dipengaruhi oleh kepentingan tertentu terjadi dalam proses implementasi kebijakan smart city Kota Tangerang dalam mewujudkan smart governance bagian dari pemerintah pusat yang berinteraksi langsung dengan masyarakat. Pemerintah Kota Tangerang mempunyai organ sampai tingkat kesatuan masyarakat yang kecil, sehingga mempunyai peranan yang cukup besar dan diikuti oleh adanya komitmen yang kuat. Keberadaan aparatur pemerintah, kekuatan sosial politik dan komponen Kota Tangerang lainnya yang tertantang dengan paradigma baru "otonomi daerah" 
diarahkan dalam kekuatan yang ada di daerah dan pengembangan kehidupan disegala bidang. Kekuatan yang ada di Kota Tangerang menampilkan dirinya benar-benar memenuhi panggilan untuk kreteria pemerintahan yang bersemangat dengan kekuatan di Kota Tangerang sendiri (potensi lokal).

Aparatur sipil negara berupaya menciptakan pengaturan, pembangunan, pemberdayaan, dan pelayanan kepada masyarakat yang tepat akurat serta kompatibel dalam hal proses kerjasama dibidang penanaman modal. Jawaban yang disampaikan informan itu sepertinya selalu diarahkan untuk menjawab secara normatif. Tetapi bagaimana bila jawaban itu dikomfrotir dengan jawaban para phak yang menerimanya. Umpamanya pada saat mengurus keperluan perizinan, yang mana penerima pelayanan dihadapkan pada kecenderungan sikap aparatur sipil negara (disposisi sikap aparatur) yang tidak sesuai dengan ketentuan yang berlaku, atau membebani penerima pelayanan dengan hal di luar ketentuan yang berlaku. Disamping jumlah aparatnya yang kurang, yang menjadi masalah adalah seringnya para pengambil keputusan tidak ada ditempat, sehingga proses perijinan memerlukan waktu yang panjang, disamping birokrasi yang ada sering menjadi hambatan.

Wajarlah bila kinerja pelayanan menyita waktu lama, karena tidak melalui prosedur dan tata cara pelayanan yang dibuat berbelit-beliti, yang mana dikarenakan kinerja petugas pelayanan lamban dan tidak responsif dalam memberikan layanan. Makanya jangan heran bila prosedur dan tata cara pelayanan yang dibuat berbelit-belit, dan kinerja petugas pelayanan yang lamban dan tidak responsif berubah menjadi lancar dan responsif. Oleh karena itu terjadi kecenderungan sikap aparatur yang mendapat respon positif dari pihak penerima layanan. Artinya, terjadi disposisi aparatur dalam memberikan pelayanan adanya kesepakatan tertentu yang membuat aparatur mau melaksanakan kinerja secara lebih responsif. Terjadinya disposisi aparatur yang merugikan atau menambah beban pembiayaan yang dilakukan oleh Pemerintah Kota Tangerang setempat untuk mencegah terjadinya kecenderungan sikap aparatur yang menyimpang dari ketentuan yang berlaku dan merugikan pihak investor.

Untuk mencegah terjadinya penyimpangan aparatur dalam smart city Kota Tangerang dalam mewujudkan smart governance disarankan dibuatkan standar operasional prosedur (SOP) yang jelas bagi aparatur yang terkait, dan diberikan reward dan punishment bagi aparat tersebut, sehingga para investor merasa nyaman menginvestasikan dananya untuk berusaha secara berkelanjutan. Kecenderungan penyimpangan yang dimaksudkan itu mungkin terjadi implementasi kebijakan smart city Kota Tangerang dalam mewujudkan smart governance. 
Karena itu itu bisa diatasi dengan meningkatkan pelaksanaan fungsi pengawasan. Fungsi pengawasan yang dimaksud itu tentu tidak terbatas pada pengawasan melekat yang dilakukan oleh masing-masing pimpinan di setiap unit kerja tetapi termasuk pengawasan fungsional dari instansi yang berwenang.

Semangat sebagai tim yang dilakukan implementasi kebijakan smart city Kota Tangerang dalam mewujudkan smart governance mempunyai sasaran dua arah, tertuju kepada masyarakat sebagai konsekuensi dari kondisi politik (political condition) dan tertuju kepada bawahan dalam lingkungan organisasi pemerintahan, sebagai konsekuensi dari kondisi kelembagaan (instituonal condition), Rasanya tidak ada bidang pekerjaan semangat sebagai tim birokrasi yang tidak ada aturannya. Semua serba diatur; bahkan saking banyaknya peraturan kerja dan kuatnya orientasi kerja aparatur pada penerapan aturan adalah bagaimana mematuhi peraturan tersebut. Soal hasil pekerjaan itu penting, dan sama dengan kepuasan penerima pelayanan yang menerima hasil pekerjaan itu penting.

Sebagai tingkat kepercayaan kebijakan diambil pimpinan mempunyai tanggungjawab mewujudkan cita-cita, harapan serta mensejahterakan dan memakmurkan masyarakat. Mempresentasikan dirinya menjadi pelaksana keinginan masyarakat, tidak memiliki kepentingan sendiri terlepas dari kepentingan masyarakat. Bertindak dari oleh dan untuk masyarakat, memperjuangkan aspirasi, tuntutan, keinginan dan mengayomi serta menyelesaikan permasalahan masyarakat dan mencarikan solusi implementasi kebijakan smart city Kota Tangerang dalam mewujudkan smart governance.

\section{Struktur Birokrasi}

Pemerintahan Kota Tangerang hingga era reformasi pemerintahan dewasa ini belum mendongkrak bagi peningkatan kesejahteraan masyarakat secara signifikan. Kondisi ini dimengerti mengingat bureaucratic structure (struktur birokrasi) para penyelenggara pemerintahan selalu dihadapkan pada proses pembelajaran menyelenggarakan pemerintahan. Akibatnya, keseluruhan energi pemerintahan lebih difokuskan pada penataan internal administrasi pemerintahan, daripada pelaksanaan pengaturan, pembangunan, pemberdayaan, dan pelayanan kepada masyarakat yang menjadi perhatian utama pernerintah Kota Tangerang.

Struktur birokrasi merupakan salah satu institusi yang paling sering bahkan secara keseluruhan menjadi pelaksana kegiatan. Keberadaan struktur birokrasi tidak saja dalam struktur pemerintah, tetapi juga ada dalam organisasi swasta, institusi dan sebagainya. Bahkan dalam kasus tertentu struktur birokrasi diciptakan untuk menjalankan struktur 
birokrasi dari implementasi kebijakan smart city Kota Tangerang dalam mewujudkan smart governance, karena melalui prosedur ini proses kebijakan secara keseluruhan aktivitas yang dilakukan untuk melaksanakan suatu kebijakan secara efektif. Kesulitan yang timbul pada tahap ini adalah sukarnya menentukan hasil kebijakan, karena adanya dampak yang tidak terantisipasi sebelumnya tingkat keberhasilan pencapaian tujuan.

Struktur birokrasi mempunyai peranan yang penting dalam keberhasilan standard operational procedure (SOP) dirumuskan secara jelas mengatur tata aliran pekerjaan implementasi kebijakan smart city Kota Tangerang dalam mewujudkan smart governance untuk kesejahteraan masyarakat. Jika hal ini tidak ada, maka sulit sekali mencapai hasil yang memuaskan karena penyelesaian masalah memerlukan penanganan dan penyelesaian khusus tanpa pola baku, fragmentasi yang sering sekali terjadi dihindari dan diatasi dengan cara sistem koordinasi baik.

Struktur birokrasi memberikan sumbangan yang besar dalam standard operational procedure dirumuskan secara jelas dukungan birokrasi yang telah ditata secara baik memperlancar keberhasilan implementasi kebijakan smart city Kota Tangerang dalam mewujudkan smart governance yang telah ditetapkan. Sebagai indikasi bahwa SOP dirumuskan secara jelas belum cukup lengkap untuk dijadikan pegangan dalam melaksanakan pengaturan, pembangunan, pemberdayaan, dan pelayanan kepada masyarakat yang bertujuan untuk meningkatkan kesejahteraan kepada masyarakat. Sumber untuk mengimplementasikan suatu kebijakan para pelaksana (implementors) mengetahui apa dan bagaimana cara melakukannya, implementasi kebijakan bisa jadi belum efektif, karena adanya ketidakefisienan struktur birokrasi dalam upaya meningkatkan kesejahteraan masyarakat.

Meskipun sumber untuk mengimplementasikan suatu kebijakan cukup dan para pelaksana (implementors) mengetahui apa dan bagaimana cara melakukannya, implementasi kebijakan smart city Kota Tangerang dalam mewujudkan smart governance instruktif sesuai dengan SOP belum efektif, karena adanya ketidakefisienan struktur birokrasi. Sampai saat penelitian ini, struktur birokrasi terlihat adanya pembagian tugas dan wewenang yang jelas dalam melaksanakan pengaturan, pembangunan, pemberdayaan, pelayanan kepada masyarakat dalam melaksanakan fungsi pemerintahan, sehingga terkesan lamban, tidak kreatif, suka menunda-nunda pekerjaan, dan selalu minta petunjuk atasan. Sebagai organisasi pemerintahan, birokrasi mempunyai struktur yang membagi semua tugas dan fungsi yang ada dalam organisasi pemerintahan. Pembagian tugas kepada semua anggota organisasi pemerintahan memberikan kemudahan mengadakan pencapaian tujuan seperti yang telah 
direncanakan sebelumnya. Hasil lapangan dimana instruktif sesuai dengan SOP dari organisasi yang telah ditetapkan masih dalam pengelompokan pekerjaan yang dikerjakan, menetapkan dan melimpahkan bekerjasama secara efektif dalam mencapain tujuan.

Berbagai struktur birokrasi pemerintahan baik berasal dari sisi internal dan eksternal organisasi pemerintahan. Faktor internal meliputi keseluruhan faktor yang ada dan berkaitan dengan organisasi itu sendiri, dimana terdapat sekelompok orang yang melakukan aktivitas kerjasama untuk mencapai tujuan jelas dirumuskan. Sedangkan faktor eksternal mencakup suatu jaringan hubungan pertukaran dengan sejumlah organisasi pemerintahan yang melibatkan diri dalam transaksi dengan tujuan jelas dirumuskan untuk memperoleh dukungan, mengatasi hambatan, melakukan pertukaran sumber daya, menata lingkungan organisasi yang kondusif, proses transformasi nilai, inovasi, maupun norma sosial yang ada.

Semakin efisien peralatan yang dimiliki, semakin memperlancar dan mempermudah mekanisme kerja roda pemerintahan Kota Tangerang mempercepat usaha untuk mencapai tujuan jelas dirumuskan. Sebaliknya, semakin tidak efisien alat-alat yang dimiliki dan digunakan, semakin menyulitkan Kota Tangerang dalam menyelenggarakan segala aktivitasnya. Oleh karena itu semakin menjauhkan penyelenggaraan pemerintahan dari citacitanya. Peralatan yang dimiliki dipergunakan dengan mudah dan menyenangkan bagi pemakainya dan justru bukannya rumit, sehingga menyulitkan bagi masyarakat yang mempergunakannya.

Pergeseran paradigma dalam pengelolaan pemerintahan sama sekali tidak berarti menghilangkan peranan kunci yang dimainkan struktur birokrasi dalam pembagian tugas antar bagian yang sangat vital atau menguasai hajat hidup orang banyak yang memang tidak diserahkan kepada publik. Dalam kegiatan tertentu keberadaan struktur birokrasi tidak dielakkan karena di bawah kondisi implementasi kebijakan smart city Kota Tangerang dalam mewujudkan smart governance lingkungan tertentu, kehadiran pembagian tugas antar bagian mutlak diperlukan guna meningkatkan efektifitas, efisiensi, dan produktifitas dalam mengejar tujuan organisasional yang telah ditetapkan dan mengontrol cara mencapainya.

Secara faktual keberadaan struktur birokrasi dimaksudkan pembagian tugas antar bagian untuk mengorganisir secara teratur suatu pekerjaan yang dilakukan oleh banyak orang. Stuktur birokrasi adalah tipe dari suatu organisasi pemerintahan yang dimaksudkan untuk mencapai tugas administratif yang besar dengan cara mengkoordinir secara sistematis (teratur) pekerjaan dari banyak orang. Dalam rumusan lain birokrasi adalah tipe organisasi yang dipergunakan pemerintahan modern untuk implementasi kebijakan smart city Kota 
Tangerang dalam mewujudkan smart governance berbagai tugas yang bersifat spesialisasi, dilaksanakan dalam sistem administrasi dan khususnya oleh aparatur sipil negara memaksimumkan efisiensi administrasi digunakan secara netral untuk mengacu kepada aspek administratif dari organisasi pemerintahan.

\section{KESIMPULAN}

Pemerintah Kota Tangerang belum efektif melaksanakan kebijakan smart city Kota Tangerang dalam mewujudkan kualitas pelayanan publik, karena teknologi informasi dan komunikasi memberikan pelayanan publik berupa akses internet, online dan digital sesuai basis data, aplikasi, dan tata kelola sebagai komponen utama yang masih belum dirasakan untuk kepentingan publik. Faktor-faktor yang mempengaruhi implementasi kebijakan smart city Kota Tangerang dalam mewujudkan kualitas pelayanan publik mencakup; (1) komunikasi mempengaruhi terkait dari semua indikator yang ada, dan masih kurang efektif indikator keterampilan; (2) Sumber daya terkait dari semua indikator yang ada, dan masih kurang efektif keterampilan tersedianya sarana dan prasarana yang dibutuhkan; (3) Disposisi terkait dari semua indikator yang ada, dan kurang efektif tingkat kepercayaan kebijakan diambil pimpinan; (4) Struktur birokrasi terkait dari semua indikator yang ada, dan yang masih kurang efektif instruktif sesuai dengan Standard Operating Procedure (SOP).

\section{DAFTAR PUSTAKA}

Ahmadjayadi, C., Subkhan, F., \& Wiradinata, M. R. (2016). New Indonesia, Dari Smart City Menuju Smart Nation. Jakarta. PT. Elex Media Komputindo Kompas Gramedia

Bungin, M. B. (2008). Penelitian Kualitatif. Jakarta: Kencana Prenada Media. Group.

Cafezio \& Morehouse, P. D. (1998). Secret of Break through Leadership. Mumbai: Jaico Publishing House.

Creswel, J. W. (1994). Research Design Qualitative \& Quantitative, Approaches.New Delhi: Sage Publications.

Dameri, R. P. (2013). Searching for Smart City Definition: A Comprehensive Proposal. International Journal of computers \& technology, 11(5), 2544-2551.

Edward III, G. C. (1980). Implementing Public Policy, Congressional. Washington: Quarterly Press.

Gaebler, T. (1993). Reinventing government: How the entrepreneurial spirit is transforming the public sector. Plume. 
Gaur, A., Scotney, B., Parr, G., \& McClean, S. (2015). Smart City Architecture and Its Applications Based on IoT. Procedia computer science, 52, 1089-1094.

Hidayatulloh, S. (2016). Internet of Things Bandung Smart City. Jurnal Informatika, 3(2).

Holle, E. S. (2011). Pelayanan Publik Melalui Electronic Government; Upaya Meminimalisir Praktek Maladministrasi Dalam Meningkatkan Public Service. Jurnal Sasi, 17(3).

Insani, P. A. (2017). Mewujudkan Kota Responsif Melalui Smart City. PUBLISIA: Jurnal Ilmu Administrasi Publik, 2(1), 25-31.

Kurnaedi, D. (2017). Penerapan "Live" Smart City Kota Tangerang. Jurnal TAM (Technology Acceptance Model), 8(1), 18-28.

Moleong, L. J. (2008). Metodologi Penelitian Kualitatif (Edisi Revisi). Bandung : Remaja Rosda Karya.

Pawito, (2007). Penelitian Komunikasi Kualitatif. Yogyakarta: LkiS.

Ramadhan, R., Arifianti, R., \& Riswanda, R. (2019). Implementasi E-Government di Kota Tangerang Menjadi Smart City (Studi Kasus Aplikasi Tangerang Live). Responsive: Jurnal Pemikiran dan Penelitian Administrasi, Sosial, Humaniora Dan Kebijakan Publik, 2(4), 140-156.

Ratama, N., \& Munawaroh, M. (2019). Perancangan Sistem Informasi Sosial Learning Untuk Mendukung Pembangunan Kota Tangerang dalam Meningkatkan Smart City Berbasis Android. Sains dan Teknologi Informasi, 5(2), 59-67.

Supangkat, S. H., Arman, A. A., \& Nugarah, I. G. B. (2015). Pengenalan dan Pengembangan Smart City. Bandung: e-Indonesia Initiatives Institut Teknologi Bandung.

Taliziduhu, N. (2003). Kybernology (Ilmu Pemerintah Baru) 1. Jakarta: Rineka Cipta.

Taliziduhu, N. (2003). Kybernology (Ilmu Pemerintah Baru) 2. Jakarta: Rineka Cipta.

Utomo, C. E. W., \& Hariadi, M. (2016). Strategi Pembangunan Smart City dan Tantangannya bagi Masyarakat Kota.Jurnal Strategi dan Bisnis, 4(2), 159-175.

Wasistiono, S. (2002). Kapita Selekta Penyelenggaraan Pemerintahan Daerah. Bandung: Fokusmedia. 